\title{
Canary Current upwelling: more or less?
}

\author{
E.D Barton $^{1^{*}}$, D.B. Field ${ }^{2}$ and C. Roy ${ }^{3}$ \\ ${ }^{1}$ IIM, CSIC, Eduardo Cabello 6, Vigo 36208, Spain \\ ${ }^{2}$ Hawai'i Pacific University, U.S.A \\ 3 Laboratoire de Physique des Océans, UMR6523 CNRS-Ifremer-IRD-UBO, \\ BP 7029280 Plouzané, France.
}

* Corresponding author Phone +34 986231930

Keywords: upwelling: alkenone unsaturation index; proxy sst; ICOADS; winds; climate change Index Terms:

\begin{abstract}
It has been hypothesized that coastal upwelling in the four major eastern boundary current systems might be intensified as global warming could result in a greater land-sea temperature gradient and hence strengthen alongshore winds. Recent research has suggested a substantial increase of upwelling intensity off Northwest Africa. Evidence there is based on the derivation of a proxy for upper ocean temperatures from the alkenone unsaturation index $\left(\mathrm{U}^{\mathrm{K}}{ }_{37}\right)$ derived from two sediment cores recovered off Cape Ghir, Morocco. An accelerating decrease of over $1^{\circ} \mathrm{C}$ during the last century was concluded for near surface temperature near the Cape. Support for this conclusion was found in an increase in Bakun's upwelling index for the same area. The evidence for a general intensification of upwelling within the whole Canary current upwelling system is examined here. Using available estimates of wind from PFEL, NCAR/NCEP, ECMWF, ICOADS and WASWind plus measured wind data from coastal meteorological stations, no evidence of a coherent intensification in winds at the regional scale off Northwest Africa is found. Moreover, sea surface temperature records from ships-of-opportunity (ICOADS data set) and also from the Pathfinder satellite AVHRR data set show a significant and correlated increase at all latitudes in the region, including in the area around Cape Ghir. It is concluded that there is no evidence for a general increase in upwelling intensity off Northwest Africa or Iberia. The apparent lowering of SST off Cape Ghir indicated by the alkenone unsaturation index can be explained by coccolithophorids (phytoplankton from which the $\mathrm{U}^{\mathrm{K}}{ }_{37}$ signal is derived) living deeper in the water column. The distribution of most phytoplankton (including coccolithophorids) will deepen and have less overlap with mixed layer temperatures as the ocean warms, resulting in a near surface temperature estimate that is increasingly biased by subsurface temperatures and lower than the actual SST.
\end{abstract}




\section{Introduction}

An apparent paradox associated with the idea of global warming is that it might lead to intensified cooling of local areas affected by coastal upwelling (Bakun, 1990). This latter phenomenon takes place along the eastern boundaries of temperate and subtropical oceans where winds predominantly blow equatorward and alongshore. The combined effect of the wind stress and the rotation of the earth produces a net offshore transport of water in the upper layer of the ocean that must be replaced by a vertical motion of colder subsurface water near the coast - upwelling (Smith, 1968). Upwelling is important for renewing the nutrient content of the upper photic layers and supports some of the most productive regions of the oceans (Ryther, 1968). Indeed, some $20 \%$ of global marine fisheries catch originates in these areas, which represent only $5 \%$ of its total extent. However, upwelling regions are highly variable and even understanding the sign of change in these regions (either warming or cooling) will be a major contribution to predicting future ocean change and fisheries productivity in these regions.

Bakun (1990) outlined a scenario wherein increased atmospheric $\mathrm{CO}_{2}$ content would diminish nocturnal cooling and enhance diurnal warming of the continental land masses at the latitudes of the upwelling regions. The strengthened thermal low pressure areas would enhance the net atmospheric pressure difference between land and ocean in these regions, thus producing an intensification of the equatorward wind and therefore of upwelling in the coastal ocean. Bakun (1990) presented evidence of a tendency for stronger upwelling in the Californian, Iberian, Moroccan and Peruvian areas during the period from 1945 to 1985 . His analysis was based on the coastal upwelling index, or rate of upwelling per unit length of coastline, which is calculated from the geostrophic wind estimated from analyzed surface atmosphere pressure fields. The index has been in wide use as an indicator of upwelling strength ever since its introduction by Bakun (1973).

More recently, McGregor et al. (2007) found strong support for the hypothesis through evidence of a dramatic lowering of inferred SSTs in the northwest African upwelling region over the last century. From analysis of two cores taken some $25 \mathrm{~km}$ off Cape Ghir, Morocco, they derive a proxy record of ocean temperature, considered to reflect SST, over the last two and a half millenia. Their alkenone unsaturation index indicates a reduction of sea surface temperature (SST) in the Cape Ghir upwelling of $1.2^{\circ} \mathrm{C}$ over the last century, coincident with the observed increase in atmospheric $\mathrm{CO}_{2}$ levels. Wind observations from the COADS - Comprehensive Ocean-Atmosphere Data Set Release 1 were used to show an increase in wind over the zone in the period after 1950 . 
Further supporting evidence was provided by the calculated upwelling (Bakun) index for the area over the same period.

However, the evidence that wind velocity is increasing and SST decreasing in the NW African upwelling region as a whole has many uncertainties. For example, the reported northward encroachment of more sub-tropical and tropical species of fish (Quéro et al., 1998; Brander et al., 2003; Graham \& Harrod, 2009) is incongruent with decreasing temperatures in this coastal zone. In global studies of trends in Large Marine Ecosystems, including the Canary Current LME (Belkin, 2009; Sherman et al., 2009), it was concluded that the "most striking result is the consistent warming" by amounts exceeding $0.6^{\circ} \mathrm{C}$ over 25 years in mid to low latitudes. Other more detailed studies like Narayan et al. (2010) and Pardo et al. (2011) have examined long term variation in the Canaries and other upwelling zones with varied results. Pardo et al. found "weakening of the upwelling intensity in the Iberian/Canary and NW African regions". In contrast, Narayan et al. concluded that coastal upwelling intensity was increasing based on evidence for increasing upwelling-favorable winds and an upwelling index based on the difference between offshore and nearshore SSTs.

As different analyses give conflicting results, the publicly available wind and SST data sets for the North Atlantic upwelling region (Figure 1) between Dakar, Senegal $\left(15^{\circ} \mathrm{N}\right)$ and Galicia, Spain $\left(43^{\circ} \mathrm{N}\right)$ are examined to document temporal trends in the intensity of the Canary Current upwelling regime in terms of the atmospheric forcing and the oceanic response. Our results clearly indicate that there is no evidence for increasing intensity of upwelling along this seaboard, in direct contrast to earlier studies. The many factors affecting reliability of the different sources of wind and SST time series are considered, before going on to explore the nature of the SST-alkenone proxy temperature relationship. The difference between the proxy and directly observed SST can be reconciled by consideration of the response to increasing stratification of the phytoplankton from which the $\mathrm{U}^{\mathrm{K}}{ }_{37}$ signal is derived.

\section{Data}

\subsection{Sources}

Various data sets were downloaded from the sources listed in Table 1 at the positions shown in Figure 1. NOAA Pacific Fisheries Environmental Laboratory (PFEL) provides the geostrophic winds calculated from the $1^{\circ}$ interpolated grid of the surface atmospheric pressure field analyzed 
every 6 hours by the Fleet Numerical Meteorology and Oceanography Center (http://www.fnmoc.navy.mil/). Details of how the calculation has evolved over the years are given in the cited web sites. Monthly averages of the 6-hourly north and east components were obtained for sites at $2^{\circ}$ intervals between latitudes 15.5 and $41.5^{\circ} \mathrm{N}$ from 1967 , when the series starts, to 2007 .

Monthly wind estimates provided by the National Center for Atmospheric Research (NCEP) Reanalysis 1 project were downloaded from the NOAA/OAR/ESRL PSD web site . These represent 4-times daily, daily and monthly values on a square $2.5^{\circ}$ global grid using a state-of-the-art analysis/forecast system to perform data assimilation using data from 1948 to the present (Kalnay et al., 1996). Details of the analysis are available on the web site.

European Centre for Medium Range Weather Forecasting (ECMWF) ERA-40 daily wind estimates, available for the period 1957-2003, were downloaded for every $2.5^{\circ}$ interval over the same range. The data are based on quantities analyzed in the ERA-40 data assimilation scheme (Uppala et al., 2005). The daily data were vector averaged to monthly values prior to further analysis.

Monthly mean northward and eastward components of observed wind velocity were downloaded from the International Comprehensive Ocean-Atmosphere Data Set (ICOADS) site, which contains the latest version of the historical sea surface records from the Voluntary Observing Fleet (Woodruff et al., 2005). Monthly mean values were obtained over the period $1960-2007$ for $1^{\circ} \mathrm{x} 1^{\circ}$ squares along the coast. Occasional gaps when no observations were available were interpolated with a cubic spline. These observations originate mainly from merchant, fishing and navy vessels, which report meteorological and sea state conditions several times per day.

Recently, Tokinaga \& Xie (2011) introduced a new sea surface wind estimate by combining ship anemometer observations of wind velocity with wind inferred from wave height in the ICOADS database. This Wave and Anemometer-based Sea-surface Wind (WASWind) dataset, available at monthly resolution on a $4^{\circ} \times 4^{\circ}$ near-global grid, is claimed to have minimized some of the bias of the ICOADS product. Monthly estimates were downloaded from the web site for the period 1950-2009.

Few direct observations of wind velocity are available from the sparse coastal meteorological network along the northwest African seaboard. Coastal wind stations included in the Climatic Data Online site of the United States National Oceanic and Atmospheric Administration (NOAA) contain no record of wind direction and therefore are not used here. However, records of surface pressure 
and temperature from two sites representing the centers of the Azores High pressure system and the Saharan Low, Santa Maria and Tessalit, respectively, were downloaded from this site.

Wind velocity data were available for three meteorological stations, all relatively low-lying, directly adjacent to the coast and well exposed to the predominant winds (Figure 1). The Yoff and Nouadhibou data were obtained from the Agence pour la Sécurité de la Navigation Aérienne en Afrique (ASECNA). The Nouadhibou airport site is $5 \mathrm{~m}$ above sea level on the peninsula of Cap Blanc near $21^{\circ} \mathrm{N}$, while the Yoff airport meteorological station lies $26 \mathrm{~m}$ above sea level near the tip of the spit of land housing Dakar near $15^{\circ} \mathrm{N}$, which juts out into the Atlantic. The original threehourly records for these sites, available for 1968-1988 and 1961-1992, respectively, were vector averaged to derive monthly vector winds. Gando airport is situated at $23 \mathrm{~m}$ height on the east coast of the island of Gran Canaria at $28^{\circ} \mathrm{N}$, which has excellent exposure to the prevailing north-easterly trade winds. The record there, available since 1960, consists of 3 recorded values of speed and direction at 0600, 1200, 1800 daily. These data, provided by the Agencia Estatal de Meteorología, Spain, were reduced to daily, then monthly vector averages for further analysis. Gando data only after 1973 are used here because of a perceptible jump in observed values coincident with the opening of the new airport terminal and presumably a change of location and instrument, unrecorded in the data file.

Two measures of sea surface temperature were obtained. The first was extracted from the same ICOADS Release 2.5 data base to obtain estimates of monthly mean SST for the same $1^{\circ}$ squares as the winds distributed along the coast from 1960 on. These data are obtained by merchant vessels of the Voluntary Observing Fleet (VOF) by bucket measurements or from the engine cooling intake. The few months with no data were filled by interpolation with a cubic spline. For a single $2^{\circ} \times 2^{\circ}$ square off Cape Ghir (Figure 1), the daily series from 1900 to present was obtained and averaged to annual means to represent the longer term variability.

The second SST data set was from the satellite Pathfinder database, in which data were available from 1985 to 2007 . In this case data at $4 \mathrm{~km}$ intervals were averaged over calendar months for each $2^{\circ}$ of latitude between the coast and the $500 \mathrm{~m}$ depth contour. Months without data because of cloud cover represented less than $5 \%$ of the record in general, with the exception of the region between $25.5^{\circ} \mathrm{N}$ and $27.9^{\circ} \mathrm{N}$, where about $25 \%$ of months were unavailable and in one case $47 \%$ were cloud contaminated. All records $<90 \%$ complete were excluded from the analysis, and the rest had gaps filled by cubic spline interpolation as above. 
In situ data from a series of cruises of the CAIBEX project on board the Moroccan Institut National de Recherche Halieutique vessel Amir Moulay Abdallah and the Spanish B/I Sarmiento de Gamboa were used. Temperature, salinity and chlorophyll data obtained with a SeaBird 911+ CTD and Seapoint fluorometer were obtained at a series of stations across the continental slope off Cape Ghir (Figure 1). Fluorescence voltage was converted to chlorophyll $\mu \mathrm{g} \mathrm{l}^{-1}$ by comparison with water bottle samples at multiple depths.

\subsection{Analyses}

Most of the analyses were based on series during the period after 1967 when the PFEL series commenced. Only meridional components of wind are used in the analysis for several reasons. First, considerable stretches of the seaboard lie roughly north-south, e.g. Iberia, near Cape Ghir and south of $22^{\circ}$ N. Second, the different locations and averaging areas for the different wind products render it difficult to select a common coastal orientation for neighboring data points given the relatively short scale changes in local orientation of the coast. Third, overall the wind flow is predominantly parallel to the coast and any changes in the alongshore component will be reflected in the meridional one.

For all data series, annual averages were calculated and trend lines were fitted by linear least squares regression. The results of the trend analysis, of course, are independent of whether annual averages, monthly means or daily data are used. The number of degrees of freedom in each series was considerably less than indicated by the number of data (n-2) because of serial correlation. Therefore the effective degrees of freedom were calculated by dividing the length of each series by its integral time scale estimated from the lagged auto-correlations following Davis (1975). An alternative expression estimating the effective degrees of freedom is given as $n\left(1-r_{1}\right) /\left(1+r_{1}\right)$, where $n$ is series length and $r_{1}$ is the auto-correlation at lag -1 of the detrended series, e.g. Santer et al. (2000). In general, the two methods gave similar results, and so exclusively the first is used here.

As a check on the robustness of the trends, they were also calculated by the non-parametric Sen's (1968) method, in which the estimate is provided by the median value of all trends between every possible pair of points. This method is insensitive to the presence of outliers, but the results are so close to the standard linear least squares trends that only the latter are used in general. However, the example of the PFEL winds is referred to later for illustration. The confidence intervals for the 
slopes were calculated by Student's t testing, using the effective number of degrees of freedom as in Emery and Thomson (1997). Comparisons with a bootstrap method employing 1000 replications of the original series showed negligible differences between the interval estimates.

\section{Results}

\subsection{Winds}

Clear differences occur between the various wind estimates in any given locality, for example, near $28^{\circ} \mathrm{N}$ (Figure 2). All monthly series indicate a strong annual cycle, superimposed on interannual, decadal and longer term variation, all of which differ between series. Standard statistics of the monthly series (Table 2) show that near $28^{\circ} \mathrm{N}$ ICOADS winds are on average the strongest of the estimated series, slightly stronger than NCEP and ECWMF, while WASWind are the weakest. The most variable of the monthly series is PFEL and the least is WASWind. The mean wind observed at Gando airport is $>50 \%$ stronger than any of the estimated winds. Data near $28^{\circ} \mathrm{N}$ are used here because of the availability of the Gando observations, but similar results obtain for the series at other latitudes.

The trends over the 40 year series length in Figure 2 vary surprisingly between different data products in the same area, as both negative and positive trends are evident. Moreover, not all wind estimates exhibit strong similarity between the interannual variability seen in their detrended annual averages, with correlation coefficient $r$ values ranging from 0.05 to 0.82 (Table 3 ). The highest cross-correlation $(\mathrm{r}=0.82)$ between the de-trended annual mean series is between ICOADS and WASWind. The variability on decadal scales evident in Figure 2 appears largest in the PFEL and smallest in the WASWind series. WASWind and ICOADS series correlate significantly with all series, though least highly with the observations of the Gando series. ECWMF and the Gando series show the lowest correlations with other series and with each other. The effective degrees of freedom in these correlations have a median value of 23 , so correlations $>0.40$ are significant at the 97.5\% level. The regression slopes between the series were relatively low, the highest being 0.74 , between Gando and WASWind, which is indicative of poor agreement in the amplitude of the interannual variability between the different wind estimates. Thus the different wind products capture some shared variability, but with many notable differences between them. 
The calculated long-term trends for annual mean wind from 1967 to 2007 vary with latitude, as well as with data sets (Figure 3), but are generally not significantly different from zero at the $97.5 \%$ level. The ICOADS wind trends, unlike the rest, indicate a statistically significant and relatively uniform change as high as $0.02 \mathrm{~m} \mathrm{~s}^{-1}$ per year towards more equatorward (negative) wind component throughout the region, which would be consistent with greater upwelling. However, the WASWind series, derived from the same data base, has non-significant trends towards more poleward (positive) wind at nearly all latitudes, which would result in more downwelling. At the extremes of the zone (south of $20^{\circ} \mathrm{N}$ and north of $37.5^{\circ} \mathrm{N}$ ) most estimates indicate weakening equatorward wind, while elsewhere the estimates are scattered about zero change. PFEL estimates suggest a zone of decreasing wind between 22 and $28^{\circ} \mathrm{N}$ not evident in the other wind re-analysis estimates. The close agreement between the LLS and Sen's trend estimates (light blue and gray points) is seen in the PFEL plot. The direct observations of coastal winds at Gando, Nouadhibou and Yoff indicate weak trends close to those of WASWind and NCEP at the same latitude. The general overlap of the $97.5 \%$ confidence intervals about the estimated trends with the zero trend axis, for all series but ICOADS, indicates the low confidence associated with these trends. Thus the sum of the observations from the different data products casts uncertainty as to whether any trend, positive or negative, is present.

\subsection{Surface pressure}

A crude measure of the average geostrophic surface wind along the African coast is given by the pressure difference between Tessalit, Mali and Santa Maria, Azores (locations in Figure 1), which represents the large scale gradient between the Saharan Low and Azores High pressure centers. While the Santa Maria record begins in the mid-1940s, and the Tessalit record commenced a decade later, there are gaps (Figure 4). Apart from isolated days of missing data, the records also have gaps extending over several months; indeed, Tessalit has hardly any year with a complete record. Nevertheless, annual averages of the available observations of surface temperature and pressure were calculated for both records and shown in Figure 4.

Given the mean pressure difference of about $10 \mathrm{mbar}$, and the separation of $3100 \mathrm{~km}$ between sites, an estimate of the mean geostrophic wind is close to $4 \mathrm{~m} \mathrm{~s}^{-1}$. A change of $0.01 \mathrm{~m} \mathrm{~s}^{-1} \mathrm{y}^{-1}$ (half that indicated by the ICOADS data in section 3.1) in the mean wind would imply a concomitant change of 0.025 mbar $^{-1} 1$ in the pressure difference, or about 1 mbar increase over 40 years 
associated with a $0.4 \mathrm{~m} \mathrm{~s}^{-1}$ change in wind. However, neither pressure series yielded any trend distinguishable from zero. The observation that the corresponding atmospheric surface temperature records also displayed no appreciable trend may be real or simply an indication that the quality of the data is insufficient for this analysis.

\subsection{Sea Surface Temperature}

The monthly mean ICOADS $1^{\circ} \times 1^{\circ}$ estimates of sea surface temperature show clear warming trends (Figure 5) over the period 1967-2007 that are roughly uniform at all latitudes, including Cabo Ghir. The magnitude of the trend is around $0.015^{\circ} \mathrm{C}^{-1}$, or $1.5^{\circ} \mathrm{C}$ per century. The $95 \%$ confidence limits generally do not include the value of zero, indicating that the trends are significant. In some latitudes the sampling boxes lie beyond the continental shelf to accommodate the position of the mercantile shipping lanes. However increasing SST was also found for the less well sampled nearshore boxes at those latitudes (not shown). Also, trends varied little between positions close to shore like Cap Blanc $\left(20^{\circ} \mathrm{N}\right)$ and those further offshore like Cape Ghir $\left(32^{\circ} \mathrm{N}\right)$. Given that the coastal transition zone affected by the cooler upwelled waters is up to $200 \mathrm{~km}$ wide, this is as expected.

The shorter (1985-2007) series of Pathfinder monthly mean SST shown in Figure 5a, shows an overall warming roughly twice that of the ICOADS SSTs and somewhat stronger south of $20^{\circ} \mathrm{N}$. In this case the data are clearly representative of the upwelling zone within the $500 \mathrm{~m}$ isobath, but the statistical confidence of the estimated trend is less because of the shorter length of the series. Because the $97.5 \%$ confidence intervals are so large, about $0.04^{\circ} \mathrm{C}^{-1}$ for degrees of freedom around 12, they are not shown in Figure 5a. Calculation of SST trends from ICOADS over the shorter Pathfinder period produces similarly high values south of $30^{\circ} \mathrm{N}$, which may be interpreted as an acceleration of the general warming trend in recent decades (the same time period in which alkenones indicate a strong cooling).

The annual means of ICOADS and Pathfinder AVHRR SST series at different latitudes were correlated at high levels of significance even though the ICOADS data were situated further offshore. For example, the detrended annual series at $33^{\circ} \mathrm{N}$ (Figure 6) were strongly correlated $(\mathrm{r}=$ 0.87, effective degrees of freedom=11) at better than the $99.5 \%$ level. This correlation was true at most latitudes, and even the weakest correlation was significant at better than the $97.5 \%$ level. Both series in Figure 6 showed similar trends, though the error bounds on the slopes are large, because of 
the limited degrees of freedom associated with the short series length and the strong interannual variability evident in the figure.

A noteworthy feature of the COADS data set is that the number of reports in the data base has varied dramatically over time. At $20^{\circ} \mathrm{N}$, near Cap Blanc, a maximum of almost 1200 reports per month in the 1970 s has been followed by a decline of $95 \%$. Other locations, e.g Cap Ghir, $33^{\circ} \mathrm{N}$ (inset in Figure 5b) followed a similar pattern, though with a smaller maximum $<300$. The 1970s peak resulted from the most intense international fishing activity off NW Africa, and in particular Cap Blanc. The continuing decline in the mercantile fleet has led to about 10 reports per month per $1^{\circ}$ square off much of NW Africa in recent decades, so that the confidence of monthly averages of parameters that vary substantially on diurnal and synoptic scales may be less certain for the later part of the record.

\subsection{Confidence in the trends}

The importance of the length of the time series and its effect on the consistency of the derived trends was examined by calculating SST trends over increasingly longer portions of the ICOADS temperature series starting in 1967. Results are displayed for three latitudes including C. Ghir, $31^{\circ} \mathrm{N}$, in Figure 7a. For sub-series shorter than 30 years, the trends varied widely, even changing sign, but the amplitude decreased as sub-series length increased, and trends settled to a near-constant warming as the full series length was approached. A similar exercise for ICOADS winds at the same latitudes (Figure 7b) likewise indicated that stable estimates of trend are not reached with series lengths $<30$ years. In the case of wind, the final trends are less uniform with time or latitude than is the case for temperature. Confidence intervals decrease as the series length increases, of course, but trends become significantly different from zero at the $97.5 \%$ significance level only after 40 years for temperature and not even after 45 years for one of the wind series. These results highlight the danger of drawing conclusions about trends from short series.

\subsection{Long term SST record}

The difference between the proxy SST records of McGregor et al. (2007) and the in situ observations is highlighted in Figure 8, where the data sets are displayed as anomalies relative to a zero in 1905 . The ICOADS data here represent the annual mean for the $2^{\circ} \mathrm{x} 2^{\circ}$ square off $\mathrm{C}$. Ghir indicated in Figure 1 after smoothing with an 11-year boxcar filter to suppress short-term 
variability. The number of ICOADS SST observations, shown on a logarithmic scale, varies from a few to several thousand per annum. Observations were scarce from 1915 to 1950, and have been consistently $>100$ per annum only since the mid-1960s. The number of reports peaked in the early 1970s, as observed in section 3.3, and has fallen to a tenth of the maximum in recent years. The two temperature series diverge, particularly in the latter half of the century. In contrast to the $1^{\circ} \mathrm{C}$ cooling indicated by the proxy series, the directly measured ICOADS SST demonstrates a warming of $1^{\circ} \mathrm{C}$.

\section{Discussion}

The present results clearly illustrate the difficulties of demonstrating definitive trends in sea surface winds and temperatures from the relatively short series available. The findings show a lack of agreement between wind trends calculated from the different wind products for the Northwest African and Iberian coasts. The apparently more robust sea surface temperature trends indicate warming along this seaboard at a rate of $\sim 1^{\circ} \mathrm{C}$ per century.

\subsection{Winds}

Evidence from other studies (e.g., Ramage,1987; Cardone et al. 1990) indicates that COADS winds are biased, and may have unrealistic trends towards higher wind speeds. Isemer (1995) showed that in every $10^{\circ} \times 10^{\circ}$ box of the Atlantic Ocean between $10^{\circ} \mathrm{S}$ and $50^{\circ} \mathrm{N}$, monthly average COADS wind speed indicated a significant increasing trend over the period late 1940s to late 1980s. However, he found no evidence of increased wind speed either at Ocean Weather Ships or in lower tropospheric wind speeds from radiosonde data over the same period. It was concluded that the general apparent increase in COADS wind velocities was not real but was an artifact of the observing and reporting system of the VOF. Moreover, Taylor et al. (2001) emphasized the lack of any agreed international calibration standard for marine wind measurements. These authors modeled severe and uncorrected distortion of the airflow around typical ship superstructure where ship anemometers are generally sited. The same authors reported many errors in VOF reports arising from computation of absolute wind velocity. Factors contributing to the overall increase of wind speed in COADS are historical discrepancies in the interpretation of Beaufort scale by mariners of different traditions, the gradual change from visual estimates of wind speed from sea state to data measured by anemometer, and the increasing height of anemometers (Thomas et al., 2008). 
To address these problems, Tokinaga \& Xie (2011) introduced the WASWind wind estimates, which correct COADS anemometer winds for heights different from $10 \mathrm{~m}$, filter out unreasonable Beaufort reports, and incorporate winds estimated from wind wave height reports. The authors showed WASWind agrees well with winds derived from the Special Sensor Microwave Imager (SSMI) satellite measurements over the last twenty years. The present results show that WASWind estimates indicate, at least in the Canaries/Iberian region, decreasing wind speeds (i.e. less upwelling) instead of the strong increases seen in the ICOADS2.5 wind. Trends derived from wind data at three coastal stations and WASWind at the same locations also appear to be in good agreement (Figure 4). The decreasing trend in this product therefore supports the idea that a large portion of the positive trend in COADS wind products can result from the aforementioned problems, and is not real.

The results here demonstrate that wind estimates from different sources differ considerably in the sign and magnitude of temporal trends and that no detectable increase in wind strength is present. In the case of the re-analysis wind products, both NCEP and ECMWF wind estimates used here benefit from uniform modelling procedures and data treatment over the whole historical record (Kistler et al., 2001). However, the available observational data base changes over time, and so, for example, ECMWF product includes assimilation of SSMI and ERS scatterometer winds, after 1987 and 1993, respectively (Uppala et al., 2005). Both re-analyses assimilate ICOADS sea surface data, albeit in slightly different ways, and so cannot be considered completely independent of ICOADS or of each other. Despite this, it has been seen clearly here that there are noteworthy differences between the series.

The limited number of meteorological stations on the African coast provides few reliable series of wind vectors. Moreover, data are difficult to access and there can be many problems with anemometer records, such as missing or poor quality data. Even when continuous records exist, the site location may be unsuitable to represent ocean winds, perhaps subject to local topographic influences, or may have been changed, as at Gando. Stations in originally well-exposed sites may experience significant building development nearby that alters the local wind patterns. Other problems relate to the change from written to automatically logged data reports, or to measurements during only part of the diurnal cycle, as in Gando. Also, there may be a lack of calibration of anemometers, which may be replaced without any notification in the record or may not be replaced until they fail. Present results show that the Gando winds were stronger than any of the comparable series. The airport is situated on wide, flat terrain on the eastern flank of Gran Canaria, well 
exposed to the trade winds. However, the vertical extension of the cone shaped volcanic island above the marine boundary layer causes a diversion and acceleration of the open ocean air flow around its flanks (Barton et al., 2001), which could readily explain why winds at Gando are stronger than over the surrounding open ocean.

\subsection{Temperatures}

It might seem that scalar SST is a more robust measure than the variable wind vector, although SST measurements are not without controversy. It is considered that the period of our main analysis (post 1967) is one of insignificant change in observational technique for SST. Changes in the predominant measurement technique from engine intake temperature to bucket temperature have recently been reported as responsible for the previously unexplained drop in ocean-averaged SST in 1945 and succeeding years (Thompson et al., 2008). Nonetheless, the longer term COADS data show a significant increasing SST trend similar to the shorter record.

The increasing SST trend during the second half of the last century presented in this paper is in direct contrast with the conclusions of McGregor et al. (2007), who reported an acceleration of a cooling trend in the upwelling area off Cabo Ghir during the last 100 years. Their finding of rapidly decreasing temperature was not compared with available records of SST because vessels of the Voluntary Observing Fleet (VOF) passed "too far from the coast to detect the upwelling". The present comparison of Pathfinder and ICOADS SSTs shows convincingly (Figure 7) that near-shore and shelf-edge SSTs are similar in their fluctuations and trends.

Attempts to categorize longer term changes in sub-surface temperature, despite their poorer spatial resolution, reveal similar increasing tendencies. Analyses at depths of $50 \mathrm{~m}$ and $100 \mathrm{~m}$, based on the World Ocean Database 2005 (WOD05; Boyer et al. 2006) show relatively uniform behavior in the sub-tropical North Atlantic, with statistically significant warming across the basin between $15^{\circ}$ and $50^{\circ} \mathrm{N}$ (Harrison \& Carson, 2007; Carson \& Harrison, 2008). Warming rates approached $0.02^{\circ} \mathrm{C}$ $\mathrm{y}^{-1}$ in the NW African region at both depths.

\subsection{Proxy and other estimates}

On the basis of their finding of decreasing proxy SST and increasing COADS wind off Cabo Ghir, McGregor et al. (2007) concluded a rapid increase of upwelling off NW Africa in general. They 
cite the Santos et al. (2005) report of increasing wind off Portugal and Morocco in the 1980s in support of their case, even though Lemos and Pires (2004) showed weakening equatorward wind between 1941 and 2000 at four Portuguese coastal sites. Moreover, the latter authors found that SSTs increased at the same sites by $0.58^{\circ} \mathrm{C}$ over the 60 years near-shore and at about one quarter as fast $200 \mathrm{~km}$ offshore. Their results indicated "a progressive weakening of the upwelling system in the last 60 years ... in contradiction to those of Bakun (1990)". Relvas et al. (2010) confirmed increasing SSTs off Portuguese while Salgado et al. (2008) found a long-term decline in the strength of upwelling at the northernmost limit of the Iberian coastal upwelling.

Other recent studies of the longer term variation in the Canary Current (and other) upwelling regions differ in their conclusions. Narayan et al. (2010), who reject re-analysis winds from ECMWF and NCAR/NCEP as less reliable (in contrast with our findings here), conclude on the basis of the COADS wind trends after 1960 that the northwest African upwelling is intensifying. Their evidence for an increase in oceanic upwelling is based on an increasing temperature contrast between near-shore and $5^{\circ}$ of longitude offshore from 1960 to present, but the conclusion of intensified upwelling does not show any evidence of decreasing near-shore temperature off Cape Ghir. Rather, the conclusion is based on greater warming offshore, although they acknowledge that changes in offshore stratification unrelated to coastal processes render the contrast a "secondary indicator". Pardo et al. (2011) report that NCEP winds have become less upwelling favorable over the last 60 years throughout the Canaries/Iberian system, except in the vicinity of Cap Ghir, and that NCEP SSTs were increasing throughout that region. Our analyses of all the available wind estimates indicate that the wind series show no significant trends in either sense, except off Iberia, where winds are becoming slightly less upwelling favorable. This is consistent with the lack of trend in the raw surface atmospheric pressure difference between the Saharan Low and Azores High.

\subsection{Reconciling the differences:}

These conflicting results can be rationalized by understanding that an increase in SST and stratification towards the end of the last century may have resulted in a different relationship between SST and temperature inferred from the alkenones. While different approaches to calibrating the relationship between alkenones and temperatures generally indicate a strong relationship between them, they also indicate large discrepancies. These discrepancies (or scatter in the relationship) have been shown to have patterns across spatial gradients that are associated with 
oceanographic changes (Prahl et al., 2010), which indicates the potential for changes in the relationship between alkenones and SST in time as well. Discrepancies could be due to different species or genetic compositions, varying nutrient concentrations, light availability, redox state of the sediments, differences in the temporal and/or, differences in the vertical production of alkenone producers (Herbert et al., 2001; Muller et al., 1998; Prahl et al., 2010). One likely scenario is that coccolithophorids would have a greater distribution in subsurface waters within the thermocline (rather than the surface) as stratification and SSTs increase and nutrient concentrations in the nearsurface diminish. Other possibilities include changes in seasonality of production of coccolithophorids (and hence alkenones) or changes in species composition. These possibilities are now explored.

A fundamental consideration of the alkenone unsaturation index $\mathrm{U}^{\mathrm{K}}{ }_{37}$ is that it is principally derived from lipids (alkenones) of coccolithophorids, whose abundance and distribution in the ocean is largely determined by light and nutrients. (Prahl et al., 1988; Brassell, 1993). The alkenones of these marine algae have varying numbers of carbon bonds as a function of temperature of the water in which they grow. Since coccolithophorids, like other phytoplankton, are found throughout the euphotic zone, they grow at temperatures within the euphotic zone range, which may include temperatures considerably lower than SST. Thus the vertical temperature structure of the water column and the related distribution of coccolithophorids must be important factors affecting the temperature in which they live.

Different species of phytoplankton (and zooplanktonic foraminifera) can have widely varying vertical distributions that vary in response to different hydrographic structures of the water column that affect temperature, light, and nutrients. Considering that coccolithophorids are a major group of phytoplankton that make up part of chlorophyll profiles, their vertical distribution would be expected to be roughly similar to chlorophyll profiles. Under conditions of extensive surface mixing, as often occurs with strong winter mixing or upwelling, a well-mixed layer forms whereby temperatures, nutrients and phytoplankton are generally uniform above the pycnocline at a constant mixed layer temperature similar to SST. In contrast, under strong stratification, temperatures are high at the surface and diminish with depth, while nutrient and chlorophyll concentrations are low at the surface and increase with depth, often with peaks within lower temperature waters. Such changes have been shown to directly affect alkenone and other temperature proxies (Malinverno et al., 2008; Field et al., 2004). 
To illustrate how phytoplankton distributions can have different relationships with temperature in the NW Africa upwelling system, variations over the shelf and slope off C. Ghir are presented. The annual cycle at a station in $750 \mathrm{~m}$ depth (Figure 9a) shows that chlorophyll is distributed closer to the surface when the water column is nearly isothermal (e.g. in winter when chlorophyll is found around the $17^{\circ} \mathrm{C}$ isotherm) and at temperatures similar to SST. In contrast, the onset of stratification in summer results in chlorophyll concentrations distributed across a range of isotherms. It is also noteworthy that the chlorophyll concentrations are reduced during summer, when stratification is high. If coccolithophorids, and hence alkenones, were produced in a 1:1 ratio with chlorophyll, it would be expected that alkenone production would be low at this time. However, coccolithophorid production in many regions, including upwelling regions, is generally known to be higher during periods of developing stratification during summer or after upwelling (Broerse et al., 2000; Schiebel et al., 2004; Prahl et al. 2010). Given this scenario, coccolith production might be expected to be highest when the water column is fairly stratified. Note that the conversion of core top alkenone values of McGregor et al. (2007) to temperature corresponds to $18.4{ }^{\circ} \mathrm{C}$, which is consistent with the location of the chlorophyll maximum during times of stratification.

Examining the cross-shore transect in October (Figure 9b) further illustrates the potential for different relationships between chlorophyll and temperature during a period of greater stratification. Closest to shore, chlorophyll is distributed primarily between the 17 and $18^{\circ} \mathrm{C}$ isotherms. Moving further offshore, from the shelf break and just beyond, the chlorophyll maximum occurs between the $18-19^{\circ} \mathrm{C}$ isotherms. Finally, the distribution of the chlorophyll maximum further offshore, where there is greater stratification, spans the $17-19^{\circ} \mathrm{C}$ isotherms, even while SST is $>21^{\circ} \mathrm{C}$. Therefore, not only can alkenone production occur in temperatures well below SST with increasing stratification, but there is potential for considerable variability between temperature and the region of highest chlorophyll concentrations, which means the vertical distribution of coccoliths is of considerable importance in determining the alkenone inferred temperature.

Additional support for the importance of vertical distributions under stratification resulting in underestimates of SST from alkenones comes from a modeling study by Giraud (2006). Giraud's model of the NW Africa upwelling region indicates that the weighted mean temperature of the distribution of smaller phytoplankton, like coccolithophorids, can easily be as much as $2^{\circ} \mathrm{C}$ lower than SST. Moreover, the areas of greatest discrepancy occur in regions where SST and stratification are high. In contrast, phytoplankton weighted mean temperature is similar to SST in the coastal areas with strong upwelling and mixing. It therefore follows, and the model indicated, that an 
increase in SST can be associated with phyotoplankton actually living in lower temperature waters (e.g. see Figure 10 of Giraud). Furthermore, the model indicated that changes in stratification and vertical distribution have much larger potential influences on weighted mean temperature than other factors like variations in seasonal production and lateral advection. However, Giraud's model was based on nutrient concentrations and temperatures fields without specific knowledge of the actual temporal and vertical distributions of coccolithophorids.

There are many direct observations of maximum coccolithophorid abundance within the thermocline (e.g. Andruleit et al., 2003; Cortes et al., 2001) and/or of alkenone production occurring at temperatures dramatically lower than SST. For example, Malinverno et al. (2008) found that summertime alkenone production in the Gulf of California was highest within the thermocline, just above where nutrients are diffusing across the nutricline and where temperatures could be $6^{\circ} \mathrm{C}$ cooler than at the sea surface. Popp et al. (2006) also found that the production of alkenones could be higher in thermocline waters of the subtropical North Pacific with strong stratification and a well developed chlorophyll maximum than in times of reduced stratification. Since sedimentation to the sea bed below originates mainly below the surface mixed layer (Coale and Bruland, 1987), it is even more likely that the chlorophyll maximum is the greater source of alkenone production and export to sediments, particularly with increasing stratification (e.g., Bentaleb et al., 1999; Ohkouchi et al., 1999; Prahl et al., 1993, 2001; Prahl and Popp, 2007; Ternois et al., 1996). Therefore $\mathrm{U}^{\mathrm{K}}{ }_{37}$ values derived from the euphotic zone often (but not always) represent thermocline, not surface temperatures, and intensification of a thermocline has the potential to result in lower inferred temperatures.

Other aspects of a warming ocean that could bias the alkenone unsaturation indices should be considered as well, such as a change in the season of greatest production of coccolithophorids. Because coccolithophorids tend to be less abundant during times of high upwelling (Broerse et al., 2000), a shift to warmer conditions would be more likely to result in greater abundances during warmer seasons, which might result in a warming bias, rather than a cooling bias (Prahl et al., 2010). However, if coccolithophorids are actually living in lower temperature waters at this time due to a distribution that has greater overlap with the thermocline, then such seasonal changes in production could exasperate the alkenone inferred cooling trend (that accompanies the increase in measured SST). Moreover, other factors like nutrient limitation could also lower the sediment derived $\mathrm{U}^{\mathrm{K}}{ }_{37}$ values under circumstances of greater stratification (Popp et al., 2006). 
Alkenones are not the only paleo proxy for upper ocean temperatures that could fail to record an increase in SST in complex coastal environments. Field (2004) analyzed many vertically stratified plankton tows to clearly show that all species of planktonic foraminifera modify their vertical distributions following chlorophyll concentrations even though some species tended to be above or below the chlorophyll maximum. The same author determined that species of foraminifera with a preferred near surface distribution could acquire a temperature signature as much as several degrees lower than SST under stratified conditions.

\subsection{Changes in alkenone inferred temperatures and upwelling in other regions}

Support for the idea of alkenones misrepresenting ocean temperature changes during the $20^{\text {th }}$ century can be found from other upwelling regions. In the Santa Barbara Basin (SBB), alkenone time series tend towards a cooling trend, rather than a long term warming, (Kennedy and Brassell, 1992; Zhao et al., 2000) when many instrumental records clearly reveal an ocean warming (McGowan et al., 1998). Furthermore, $\delta^{18} \mathrm{O}$ records from several species of planktonic foraminifera from sediment cores in the SBB also fail to indicate a warming trend, although increases in the abundances of tropical and subtropical species do match variations in SST and reflect long term warming (Field 2004; Field et al., 2006). These differences are also reconciled by the coccolithophorids and foraminifera living deeper within the thermocline of a more stratified ocean environment but the different hydrographic structure increases the abundances of tropical and subtropical species. Such observations also suggest that a good proxy to complement alkenone records or $\delta^{18} \mathrm{O}$ records is the assemblages of microplankton, such as foraminifera, coccolithophores, or cysts of autotrophic flagellates.

While alkenones may fail to resolve decadal-scale ocean warming trends in some dynamic coastal, upwelling environments, such observations do not limit the application of alkenone indices to many paleo applications. Open ocean regions often have better developed mixed layers with less complex gradients across the thermocline. Furthermore, alkenone indices are often used to address temperature changes of much greater magnitude than the $\sim 1^{\circ} \mathrm{C}$ warming trend of the last century; smaller changes in temperature are often more difficult to resolve than larger glacial/interglacial changes. Nonetheless, we emphasize that alkenones (like other proxies) should be used in conjunction with other proxies. 
Additionally, the complex nature of upwelling systems and the strong gradients in temperature that occur across the euphotic zone, make reconstruction of environmental change there particularly difficult. It is clear that the response to global warming in different regions of eastern boundary currents is complex and must be examined independently for any particular region. For example, off California, Di Lorenzo et al. (2005) found that upwelling favorable winds were stronger after 1977 then in the decades prior. While such an increase in winds may be related to Bakun's (1990) proposed mechanism, the coastal ocean warmed during this time period due to atmospheric forcing, presumably from the increase in greenhouse gasses (Di Lorenzo et al., 2005). Thus, regardless of whether continental warming results in an increase in alongshore winds and a shoaling of isotherms towards the surface, the uppermost ocean may still warm. Such a scenario would further increase the gradient across the thermocline, resulting in a greater difficulty in resolving temperature variations with proxies from planktonic organisms.

Bakun's hypothesised mechanism may be occurring on interannual (Bakun et al., 2010) or longer timescales (Gutierrez et al., 2009) off the coast of Peru. On interannual timescales, winds increase during El Niño events, when water vapor concentrations increase and land temperatures increase (Bakun et al., 2010). However, due to the deepening of the thermocline from large scale forcing, the ocean warms despite the increase in upwelling favorable winds. Off the coast of Pisco, Peru, alkenone unsaturation indices also indicate a strong cooling trend, which is supported by SST observations from coastal stations (Gutierrez et al., 2009). However, the alkenone derived cooling is greater than the SST cooling, even though the sediment cores were recovered further from the coast and a clear warming trend is apparent further offshore (Gutierrez et al., 2009). This discrepancy could be explained in that increased upwelling during some parts of the year combined with tendencies towards stronger stratification in others (and further offshore) results in a more strongly developed chlorophyll maximum and an alkenone saturation index that exaggerates the actual cooling. However, neither strong cooling nor warming can be ruled out in this particular region. Regardless of the actual mechanisms of change occurring off of central Peru, it is clear that multiple proxies, along with careful examination of instrumental records, are necessary for clear understanding of past changes.

\section{Conclusions}

Examination of available wind, atmospheric pressure and SST records from the Canaries-Iberian upwelling region indicate that: 
- sea surface temperature is increasing near the coast at all latitudes throughout the region at a rate $>0.01^{\circ} \mathrm{C} \mathrm{y}^{-1}$;

- wind estimates from different data bases can differ in trends and variability, but WASWind estimates appear to agree well with the few available coastal stations;

- no statistically significant change in meridional (upwelling favorable) wind component is found, except off Iberia, where winds are becoming slightly less upwelling favorable;

- there is no evidence for a general intensification of upwelling in this large marine ecosystem, contrary to the hypothesis of Bakun (1990) and the conclusions of McGregor et al. (2007).

Consideration of the factors influencing the alkenone unsaturation index $\mathrm{U}^{\mathrm{K}}{ }_{37}$ derived from coccolithophorids and other phytoplankton leads to the conclusions that:

- the use of the alkenone unsaturation index as a proxy for sea surface temperature is subject to considerable uncertainty, and should not be used uncritically;

- further examination of the mechanisms causing deviations in the alkenone unsaturation index-sea surface temperature relationship is required to understand paleo records (particularly those where SST changes are of lower magnitude);

- use of the index should preferably be made in conjunction with the examination of other proxies that are sensitive to changes in the structure of the water column (e.g. microfossils).

In general, caution should be exercised in the use of proxy temperature estimates and their extrapolation to regional scales from a single proxy and/or sediment site. Multiple proxies and sediment cores are clearly needed in oceanographic reconstructions.

\section{Acknowledgments}

We thank Fred Prahl (College of Earth, Ocean, and Atmospheric Sciences, Oregon State University), and Andy Bakun (Rosenstiel School of Marine and Atmospheric Science, University of Miami) for reviewing the manuscript and giving insightful comments. Exchanges with Daniel Franklin (School of Environmental Sciences, University of East Anglia), J uan Carlos Herguera García (CICESE),_Jeremy Young (Natural History Museum, London) and Gordon Wolfe (Department of Biological Sciences, California State University, Chico) were most useful. JeanLuc Redelsperger provided insight on the African meteorological observations. Bruno Blanke (LPO/CNRS) provided access to the ECMWF data. Dominique Dagorne (IRD) processed the 
Pathfinder data. The University of Brest provided financial support to E.D.B. during a sabbatical visit. Financial support during writing up was provided by Caibex (CTM2007 -66408-CO202/MAR) and RAIA (0520_RAIA_CO_1_E). Graphics were prepared with GMT http://gmt.soest.hawaii.edu/, Gri http://gri.sourceforge.net/and ImageMagick http://www.imagemagick.org/. 


\section{Figure Legends}

Figure 1 Canaries-Iberian upwelling region. Colored symbols indicate the locations of data series as described in section 2 Data. The white square represents the area of the long term ICOADS temperature series. The yellow line shows the position of in situ hydrographic observations off C. Ghir.

Figure 2 Time series of monthly meridional wind estimates near $28^{\circ} \mathrm{N}$ (light curves). Annual means (heavy curves) and linear least squares trends are superimposed. Positions are shown in Figure 1.

Figure 3 (a) Trends of meridional monthly wind estimates 1967-2007 from ECMWF, NCEP and PFEL as a function of latitude (solid lines). Broken lines indicate 97.5\% confidence limits.

(b) Trends and confidence limits for ICOADS, WASWind, Yoff, Nouadhibou and Gando wind series. See Figure 1 for positions. Positive trends imply less upwelling

Figure 4 Time series of surface air temperature (solid lines), surface atmospheric pressure (dashed lines) and number of daily observations per year (open symbols) at Tessalit, Mauretania (red) and Santa Maria, Azores (blue). See Figure 1 for positions.

Figure 5 (a) Trends of ICOADS SST1967-2007 and 1985-2007 and Pathfinder AVHRR 1985-2007 as a function of latitude (solid lines). Broken lines indicate $97.5 \%$ confidence limits. See Figure 1 for positions.

(b) Average number of ICOADS SST observations per $1^{\circ}$ square as a function of latitude. Dashed lines indicate maximum and minimum values. Inset shows time history of observations in square at $33^{\circ} \mathrm{N}$.

Figure 6 Demeaned series of annual averages of ICOADS and Pathfinder AVHRR SST at $33^{\circ} \mathrm{N}$, near Cape Ghir. Correlation coefficient between the two series of 0.87 is significant at the $99.5 \%$ level for the 11 effective degrees of freedom. Trend lines are shown.

Figure 7 Trend values calculated as a function of series length for (a) ICOADS SST (b) ICOADS meridional wind component at three latitudes. Trend values are shown as solid lines and $97.5 \%$ confidence limits as broken lines. 
Figure 8 Proxy and observed SST series off C. Ghir. The two proxy series, from alkenone unsaturation indices, are taken from McGregor et al. (2007) while the ICOADS series represents average temperatures for the $2^{\circ} \times 2^{\circ}$ square shown in Figure 1. The ICOADS series is filtered with an 11-year running mean. Series are shown relative to a common zero in 1905. The number of ICOADS observations per year are shown on logarithmic scale.

Figure 9 (a) Annual cycle of temperature $\left({ }^{\circ} \mathrm{C}\right)$ at a station in $750 \mathrm{~m}$ depth off C. Ghir in 2009.

Chlorophyll $\left(\mu \mathrm{g} \mathrm{l}^{-1}\right)$ contours are overlaid in green. Sample profiles are indicated by the vertical lines. The December station is wrapped around from 2008.

(b) Variation of temperature and chlorophyll across the C. Ghir shelf and slope in October 2009. Station positions are shown by vertical lines. The position of the $750 \mathrm{~m}$ station is arrowed. 


\section{References}

Alvarez-Salgado,X.A., Labarta, U.M., Fernandez-Reiriz, J., Figueiras, F., Roson, G., Piedracoba, S., Filgueira, R., and Cabanas, J.M. (2008) Renewal time and the impact of harmful algal blooms on the extensive mussel raft culture of the Iberian coastal upwelling system (SW Europe). Harmful Algae, 7, 849-855, doi:10.1016/j.hal.2008.04.007

Andruleit, H., S. Stäger, U. Rogalla, P. Čepek (2003). Living coccolithophores in the northern Arabian Sea: ecological tolerances and environmental control, Marine Micropaleontology, 49, 1, 157-181.

Bakun, A. (1973) Daily and Weekly Upwelling Indices, West Coast of North America, 1967-73. NOAA Technical Report NMFS SSRF-693, 114pp.

Bakun, A. (1990) Global Climate Change and Intensification of Coastal Ocean Upwelling. Science, 247, 4939, pp198-201, doi: 10.1126/science.247.4939.198.

Bakun, A., Field, D.B., Redondo-Rodríguez, A., Weeks, S.J. (2010) Greenhouse gas, upwellingfavourable winds, and the future of coastal ocean upwelling ecosystems. Global Change Biology, $16,1213-1228$.

Barton, E.D., Basterretxea, G., Flament, P., Mitchelson-Jacob, E.G., Jones, B., Arístegui, J., and Herrera, F.(2000) Lee of Gran Canaria. Journal of Geophysical Research, 105, 17173-17193.

Bentaleb, I., Grimalt, J. O., Vidussi, F., Marty, J.-C., Martin, V., Denis, M., Hatte, C ., and Fontugne, M.(1999) The C37 alkenone record of seawater temperature during seasonal thermocline stratification, Marine Chemistry, 64, $301-313$.

Belkin, I.M. (2009) Rapid warming of Large Marine Ecosystems. Progress in Oceanography, 81, 207-213.

Boyer, T. P., Garcia, H. E., Johnson, D. R., Locarnini, R. A., Mishonov, A. V., Pitcher, M. T., Baranova, O. K., and Smolyar, I. V. (2006) World Ocean Database 2005. NOAA Atlas NESDIS 60, $190 \mathrm{pp}$. 
Brander, K., Blom, G., Borges, M. F. „Erzini, K., Henderson, G., MacKenzie, B.R., Mendes, H.,Ribeiro, J., Santos A.M. P. and Toresen, R. (2003). Changes in fish distribution in the eastern North Atlantic; are we seeing a coherent response to changing temperature?. ICES Mar. Sci. Symp., 219, 261-270.

Brassell, S. C. (1993) Applications of biomarkers for delineating marine paleoclimatic fluctuations during the Pleistocene. In Organic Geochemistry: Principles and Applications (eds. M. H. Engel and S. A. Macko). Plenum Press, pp. 699-738.

Broerse, A.T.C., Brummer, G.-J.A., and van Hinte, J.E. (2000) Coccolithophore export productionin response to monsoonal upwelling off Somalia (northwestern Indian Ocean). Deep-Sea Research, 47 (9-11): 2207-2227.

Cardone, V. J., Greenwood, J. G., and Cane, M. A. (1990) Trends in historical marine wind data. Journal of Climate, 3, 113-127.

Carson, M. and Harrison, D.E.(2008) Is the Upper Ocean Warming? Comparisons of 50-Year Trends from Different Analyses. Journal of Climate, 21, 2259-2268, doi: 10.1175/2007JCLI2002.1

Coale, K.H. and Bruland, K.W. (1987) Oceanic Stratified Euphotic Zone as Elucidated by ${ }^{234} \mathrm{Th}:{ }^{238} \mathrm{U}$ Disequilibria. Limnology and Oceanography, 32, 1, 189-200.

Cortes, M.Y., Bollman, J., and Thierstein, H.R.(2001) Coccolithophore ecology at the HOT station ALOHA, Hawaii, Deep-Sea Research II, 48, 1957-1981.

Davis, R.E. (1976) Predictability of sea surface temperature and sea level pressure anomalies over the North Pacific Ocean. Journal of Physical Oceanography, 6 249-266.

Di Lorenzo E., Miller, A.J., Schneider, N., and McWilliams, J.C. (2005) The warming of the California current: dynamics and ecosystem implications. Journal of Physical Oceanography, 35, $336-362$. 
Emery, W.J. and Thomson, R.E. (1997) Data Analysis Methods in Physical Oceanography. Pergamon, Oxford.

Field, D. B. (2004) Variability in vertical distributions of planktonic foraminifera in the California Current: Relationships to vertical ocean structure. Paleoceanography, 19, PA2014, doi:10.1029/2003PA000970,

Field, D. B., Baumgartner, T. R.,Charles, C. D., Ferreira-Bartrina, V., and Ohman,M. D. (2006) Planktonic Foraminifera of the California Current Reflect 20th-Century Warming. Science, 311, 63-66.

Giraud, X. (2006) Modelling an alkenone-like proxy record in the NW Africa Upwelling, Biogeosciences, 3, 251-269.

Graham, C. T. and Harrod, C. (2009) Implications of climate change for the fishes of the British Isles. Journal of Fish Biology, 74, 1143-1205, doi:10.1111/j.1095-8649.2009.02180.x

Gutiérrez, D., Sifeddine, A., Field, D.B., Ortlieb, L., Vargas, G., Chávez, F.P., Velazco, F., Ferreira, V., Tapia, P., Salvatteci, R., Boucher, H., Morales, M.C., Valdés, J., Reyss, J.-L., Campusano, A., Boussafir, M., Mandeng-Yogo, M., García, M., and Baumgartner, T. (2009) Rapid reorganization in ocean biogeochemistry off Peru towards the end of the Little Ice Age, Biogeosciences, 6, 835-848, doi:10.5194/bg-6-835-2009.

Haidar, A.T. and Thiersten, H.R. (2001) Coccolithophore dynamics off Bermuda (N. Atlantic), Deep-Sea Research II, 48, 1925-1946.

Harrison, D. E. and Carson, M. (2007) Is the world ocean warming? Upper-ocean temperature trends: 1950-2000. Journal of Physical Oceanography, 37, 174-187.

Herbert, T. D. (2001) Review of alkenone calibrations (culture, water column, and sediments) . Geochemistry, Geophysics, Geosystems, 2. 
Isemer, H.-J. (1995) Trends in marine surface winds speed: Ocean weather stations versus voluntary observing ships. Proceedings of the International COADS Workshop, Kiel, Germany, NOAA Environmental Research Laboratories and Institut fur Meereskunde, 68-84.

Kalnay, E., Kanamitsu, M.,. Kistler, R , Collins, W., Deaven, D., Gandin, L., Iredell, M.,Saha, S., White, G., Woollen, J., Zhu, Y., Leetmaa, A., Reynolds, R., Chelliah, M., Ebisuzaki, W., Higgins, W., Janowiak, J., Mo, K., Ropelewski, C., Wang, J., Jenne, R., and Joseph, D. (1996) The NCEP/NCAR 40-Year Reanalysis Project. Bulletin American Meteorological Society, 77, 437-471.

Kennedy, J. A. and Brassell, S. C. (1992) Molecular records of twentieth-century El Nino events in laminated sediments from the Santa Barbara basin, Nature, 357, 62 - 64 .

Lemos, R. and Pires, H. (2004) The upwelling regime off the west Portuguese coast, 1941 - 2000, International Journal of Climatology, 24, 511 - 524, doi:10.1002/joc.1009.

Malinverno E., Prahl, F.G., Popp, B.N., and Ziveri, P. (2008) Alkenone abundance and its relationship to the coccolithophore assemblage in Gulf of California surface waters. Deep-Sea Research I, 55 (2008), pp. 1118-1130. Doi/10.1016/j.dsr.2008.04.007

McGowan, J.A., Cayan, D.R., and Dorman, L.M. (1998) Climate-ocean variability and ecosystem response in the Northeast Pacific. Science, 281, 210 \pm 217.

McGregor, H., Dima, M., Fischer, H., and Mulitza, S. (2007) Rapid 20th-century increase in coastal upwelling off northwest Africa, Science, 315, 637 - 639, doi:10.1126/science.1134839..

Moat, B.I., Yelland, M.J., Pascal, R.W., and Molland, A.F. (2005) An overview of the airflow distortion at anemometer sites on ships. International Journal Climatology, 25, 997-1006, doi: 10.1002/joc. 1177

Muller P. J., Kirst, G., Ruhland, G., von Storch, I., and Rosell-Mele, A. (1998) Calibration of the alkenone paleotemperature index UK'37 based on core-tops from the eastern South Atlantic and the global ocean $\left(60^{\circ} \mathrm{N}-60^{\circ} \mathrm{S}\right)$. Geochimica et Cosmochimica Acta 62, 1757-1772. 
Narayan, N., Paul, A., Mulitza, S., and Schulz, M. (2010) Trends in coastal upwelling intensity during the late 20th century. Ocean Sciences, 6, 815-823, doi:10.5194/os-6-815-2010

Ohkouchi, N., Kawamura, K., and Okada,H. (1999) Depth ranges of alkenone production in the central Pacific Ocean, Global Biogeochemical Cycles, 13, 695 - 704.

Pardo, P.D., Padín, X. A., Gilcoto, M., Farina-Busto, L., and Pérez, F.F. (2011) Evolution of upwelling systems coupled to the long-term variability in sea surface temperature and Ekman transport. Climate Research, 48: 231-246, doi: 10.3354/cr00989.

Popp, B.N., Bidigare, R. R., Deschenes, B., Laws, E.A., Prahl, F.G., Tanimoto, J.K., and Wallsgrove, R. J. (2006) A new method for estimating growth rates of alkenone-producing haptophytes. Limnology and Oceanography Methods 4, 114-129.

Prahl F. G., Muehlhausen L. A., and Zahnle D. L. (1988) Further evaluation of long-chain alkenones as indicators of paleoceanographic conditions. Geochimica et Cosmochimica Acta 52, 2303-2310.

Prahl F. G., Collier R. B., Dymond J., Lyle M., and Sparrow M. A. (1993) A biomarker perspective on prymnesiophyte productivity in the northeast Pacific Ocean. Deep-sea Res. I 40, 2061-2076.

Prahl F. G., Pilskaln C. H., and Sparrow M. A. (2001) Seasonal record for alkenones in sedimentary particles from the Gulf of Maine. Deep-Sea Res. I 48, 515-528.

Prahl F. G. and Popp B. N. (2007) Biogeochemical assessment of alkenone export depth in the summertime euphotic zone of the Gulf of California. Extended Abstracts Presented at the ACS National Meeting 47, 2, 483-487.

Prahl, F. G., Rontani, J.-F., Zabeti, N., Walinsky, S.E., and Sparrow, M.A. (2010) Systematic pattern in U K'37-Temperature residuals for surface sediments from high latitude and other oceanographic settings. Geochimica et Cosmochimica Acta, 74, 131-143, doi:10.1016/j.gca.2009.09.027

Quéro, J.-C., Du Buit, M.-H., Vayne,, J.-J. (1998) Les observations de poissons tropicaux et le réchauffement des eaux dans l'Atlantique européen. Ocenanologica Acta, 21, 2, 345-351. 
Ramage, C. R. (1987) Secular changes in reported surface wind speeds over the ocean. Journal of Climate Applied Meteorology, 26, 525-528.

Relvas, P., Luis, J., and Santos, A. M. P. (2009) Importance of the mesoscale in the decadal changes observed in the northern Canary upwelling system. Geophysical Research Letters, 36, L22601, doi:10.1029/2009GL040504.

Ryther, J.H. 1969. Photosynthesis and fish production in the sea. Science 166:72-76.

Santer, B.D., Wigley, T. M. L., Boyle, J. S., Gaffen, D. J., Hnilo, J. J., Nychka, D., Parker, D. E., and Taylor, K. E. (2000) Statistical significance of trends and trend differences in layer-average atmospheric temperature time series. Journal of Geophysical Research, 105, D6, 7337-7356.

Santos, A., Kazmin, A., and Peliz, A. (2005) Decadal changes in the Canary upwelling system as revealed by satellite observations: Their impact on productivity, Journal of Marine Research, 63, $359-379$.

Schiebel, R., Zetner, A., Treppke, U.F., Wanniek, J.J., Bollmann, J., Rixen, T., and Hemleben, C. (2004) Distribution of diatoms, coccolithophores and planktic foraminifers along a trophic gradient during SW monsoon in the Arabian Sea, Marine Micropaleontology, 51, 345-371.

Sen, P. K. (1968) Estimates of the regression coefficient based on Kendall's tau. Journal of the American Statistical Association, 63, 1379-1389.

Sherman, K., Belkin, I., Friedland, K., O’Reilly, J., and Hyde, K. (2009) Accelerated Warming and Emergent Trends in Fisheries Biomass Yields of the World's Large Marine Ecosystems. Ambio, 38, $4,215-24$.

Smith, R.L. 1968 Upwelling. Oceanography and Marine Biology, Annual Review, 6, 11-47.

Taylor, P.K., Kent, E.C., Yelland, M.J., and Moat, B.I. (1999) The accuracy of marine surface winds from ships and buoys. CLIMAR 99, WMO Workshop on Advances in Marine Climatology, Vancouver, 59-68. 
Ternois, Y., Sicre, M.-A., Boireau, A., Marty, J.-C., and J.-C. Miquel (1996) Production pattern of alkenones in the Mediterranean Sea, Geophysical Research Letters, 23, 3171 - 3174.

Thomas, B.R., Kent, E.C., Swail, V.R., and Berry, D.I. (2008) Trends in ship wind speeds adjusted for observation method and height. International Journal Climatology, 28, 747-763, doi: 10.1002/joc. 1570

Thompson, D. W. J., Kennedy, J. J., Wallace,, J. M., and Jones, P. D. (2008) A large discontinuity in the mid-twentieth century in observed global-mean surface temperature. Nature, 453, 646-9, doi:10.1038/nature06982

Tokinaga, H. and S.-P. Xie (2011) Wave- and Anemometer-Based Sea Surface Wind (WASWind) for Climate Change Analysis. Journal of Climate, 24, 267-285, doi: 10.1175/2010JCLI3789.1

Uppala, S.M., Kållberg, P.W., Simmons, A.J., Andrae, U, da Costa, Bechtold, V., Fiorino, M., Gibson, J.K., Haseler, J., Hernandez, A., Kelly, G.A., Li, X., Onogi, K., Saarinen, S., Sokka, N., Allan, R.P., Andersson, E., Arpe, K., Balmaseda, M.A., Beljaars, A.C.M., van de Berg, L., Bidlot, J., Bormann, N., Caires, S., Chevallier, F., Dethof, A.,Dragosavac, M., Fisher, M., Fuentes, M., Hagemann, S., Hólm, E., Hoskins, B.J., Isaksen, L., Janssen, P.A.E.M., Jenne, R., McNally, A.P., Mahfouf, J.-F., Morcrette, J.-J., Rayner, N.A., Saunders, R.W., Simon, P., Sterl, A., Trenberth, K.E., Untch, A., Vasiljevic, D., Viterbo, P., and Woollen, J. (2005) The ERA-40 re-analysis. Quarterly Journal Royal Meteorological Society, 131, 2961-3012.

Woodruff, S.D., Diaz, H.F., Worley, S.J., Reynolds, R. W., and Lubker, S. J. (2005) Early ship observational data and ICOADS. Climatic Change, 73, 169-194

Zhao M., Eglinton G., and Schimmelmann A. (2000) An alkenone (UK37) quasi-annual sea surface temperature record (A.D. 1440 to 1940) using varved sediments from the Santa Barbara Basin. Org. Geochem. 31, 903-917. 
Table 1 Data sources

\begin{tabular}{|l|l|l|l|}
\hline \multicolumn{1}{|c|}{ Data base } & \multicolumn{1}{|c|}{ Source } & \multicolumn{1}{c|}{$\begin{array}{c}\text { Latitude } \\
\text { range }\end{array}$} & \multicolumn{1}{c|}{ Period } \\
\hline PFEL & http://www.pfeg.noaa.gov/ & $15.5-41.5^{\circ} \mathrm{N}$ & $\begin{array}{l}1967- \\
2007\end{array}$ \\
\hline $\begin{array}{l}\text { NCAR/ } \\
\text { NCEP }\end{array}$ & http://www.esrl.noaa.gov/psd & $15.0-42.5^{\circ} \mathrm{N}$ & $\begin{array}{l}1967- \\
2007\end{array}$ \\
\hline $\begin{array}{l}\text { ECWMF } \\
\text { ERA-40 }\end{array}$ & http://www.ecmwf.int & & $1957-$ \\
& & $15.0-40.0^{\circ} \mathrm{N}$ & 2003 \\
\hline ICOADS & http://icoads.noaa.gov/ & & $1960-$ \\
\hline & & $15.0-41.0^{\circ} \mathrm{N}$ & 2007 \\
\hline WASWind & http://iprc.soest.hawaii.edu/users/tokinaga/waswind.html & & $1950-$ \\
Pathfinder & http://www.nodc.noaa.gov/sog/ & $16.0-44.0^{\circ} \mathrm{N}$ & 2009 \\
\hline $\begin{array}{l}\text { Nouadhibou, } \\
\text { Mauretania }\end{array}$ & http://www.asecna.aero/ ASECNA & $15.0-44.0^{\circ} \mathrm{N}$ & $\begin{array}{l}1982- \\
2007\end{array}$ \\
\hline $\begin{array}{l}\text { Yoff, } \\
\text { Mauretania }\end{array}$ & http://www.asecna.aero/ ASECNA & $20^{\circ} 55^{\prime} \mathrm{N}$ & $1968-$ \\
$17^{\circ} 02^{\prime} \mathrm{W}$ & 1988 \\
\hline $\begin{array}{l}\text { Gando, Las } \\
\text { Palmas, } \\
\text { Spain }\end{array}$ & http://www.aemet.es AEM & $14^{\circ} 44^{\prime} \mathrm{N}$ & $1961-$ \\
$17^{\circ} 29^{\prime} \mathrm{W}$ & 1992 \\
\hline
\end{tabular}


Table 2 Basic statistics of wind series near $28^{\circ} \mathrm{N}$

\begin{tabular}{|c|c|c|c|c|c|c|c|}
\hline & Position & $\begin{array}{l}\text { Mean } \\
\mathrm{m} \mathrm{s}^{-1}\end{array}$ & $\begin{array}{l}\text { Standard } \\
\text { deviation }\end{array}$ & Kurtosis & Skew & Maximum & Minimum \\
\hline PFEL & $27.5^{\circ} \mathrm{N} 13.5^{\circ} \mathrm{W}$ & -4.80 & 2.66 & 2.47 & 0.11 & 2.62 & -11.39 \\
\hline ICOADS & $27.0^{\circ} \mathrm{N} 16.0^{\circ} \mathrm{W}$ & -5.41 & 2.28 & 2.52 & 0.03 & 0.65 & -11.33 \\
\hline ECMWF & $27.5^{\circ} \mathrm{N} 15.0^{\circ} \mathrm{W}$ & -5.11 & 1.86 & 3.11 & 0.54 & 0.96 & -9.04 \\
\hline NCEP & $27.5^{\circ} \mathrm{N} 15.0^{\circ} \mathrm{W}$ & -5.36 & 1.99 & 2.82 & 0.44 & 0.76 & -9.40 \\
\hline WASWind & $28.0^{\circ} \mathrm{N} 16.0^{\circ} \mathrm{W}$ & -4.23 & 1.52 & 3.19 & 0.60 & 0.77 & -7.44 \\
\hline Gando & $27.9^{\circ} \mathrm{N} 15.4^{\circ} \mathrm{W}$ & -7.58 & 2.42 & 2.21 & -0.30 & -2.80 & -14.40 \\
\hline
\end{tabular}


Table 3 (Lower left) Linear correlations $r$ between detrended annually averaged wind series near $28^{\circ} \mathrm{N}$; bold values are significant at the $97.5 \%$ level; (top right) slope of the regression between detrended series.

\begin{tabular}{|l|l|l|l|l|l|l|}
\hline & PFEL & ICOADS & ECMWF & NCEP & WASWind & Gando \\
\hline PFEL & - & 0.29 & 0.18 & 0.33 & 0.24 & 0.22 \\
\hline ICOADS & $\mathbf{0 . 5 8}$ & - & 0.27 & 0.55 & 0.43 & 0.38 \\
\hline ECMWF & 0.31 & $\mathbf{0 . 6 1}$ & - & 0.59 & 0.29 & 0.07 \\
\hline NCEP & $\mathbf{0 . 4 1}$ & $\mathbf{0 . 7 0}$ & 0.31 & - & 0.61 & 0.45 \\
\hline WASWind & $\mathbf{0 . 5 3}$ & $\mathbf{0 . 8 2}$ & $\mathbf{0 . 4 2}$ & $\mathbf{0 . 7 4}$ & - & 0.74 \\
\hline Gando & 0.25 & 0.35 & 0.05 & $\mathbf{0 . 4 8}$ & $\mathbf{0 . 4 7}$ & - \\
\hline
\end{tabular}




\section{Figure}

Click here to download high resolution image

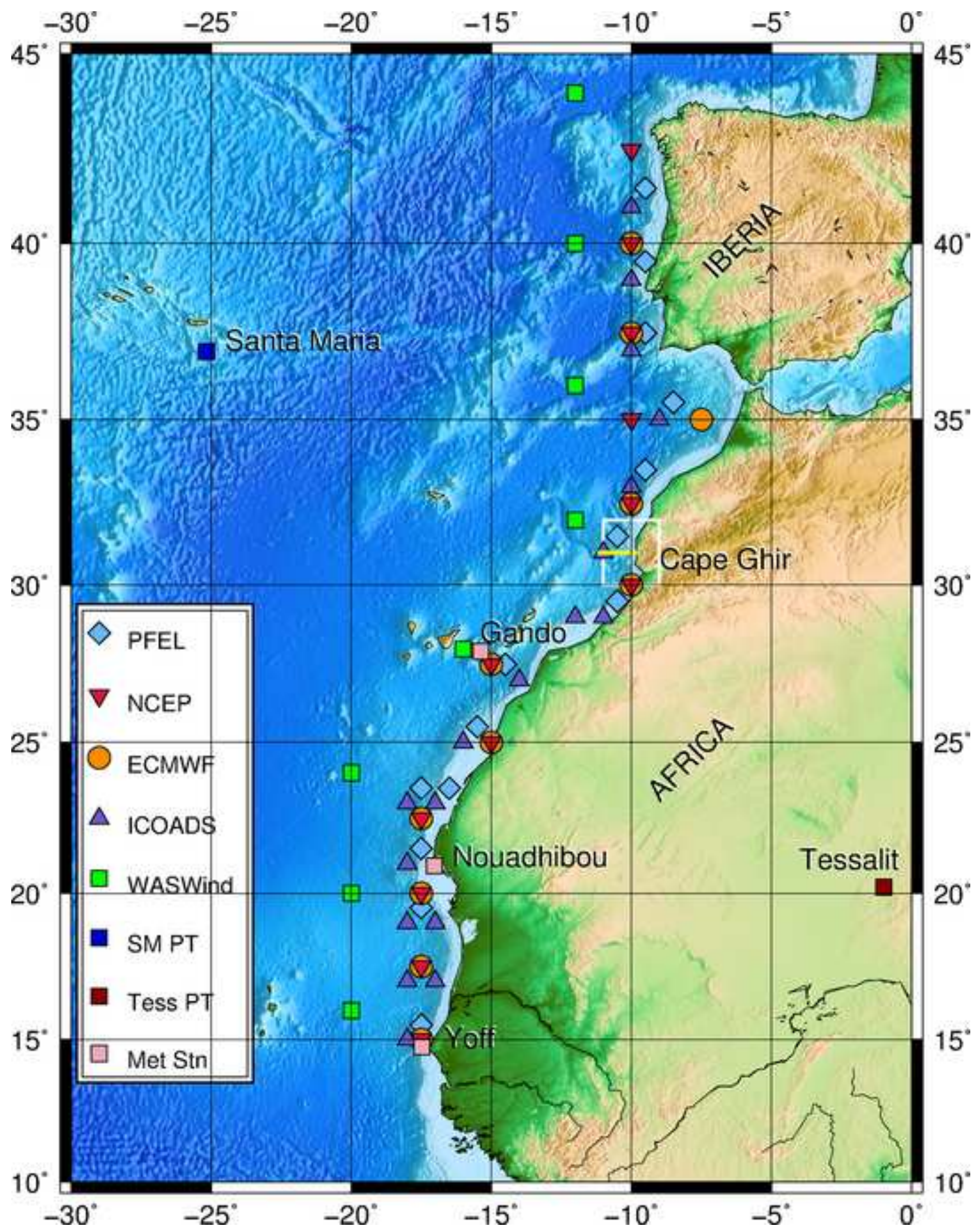



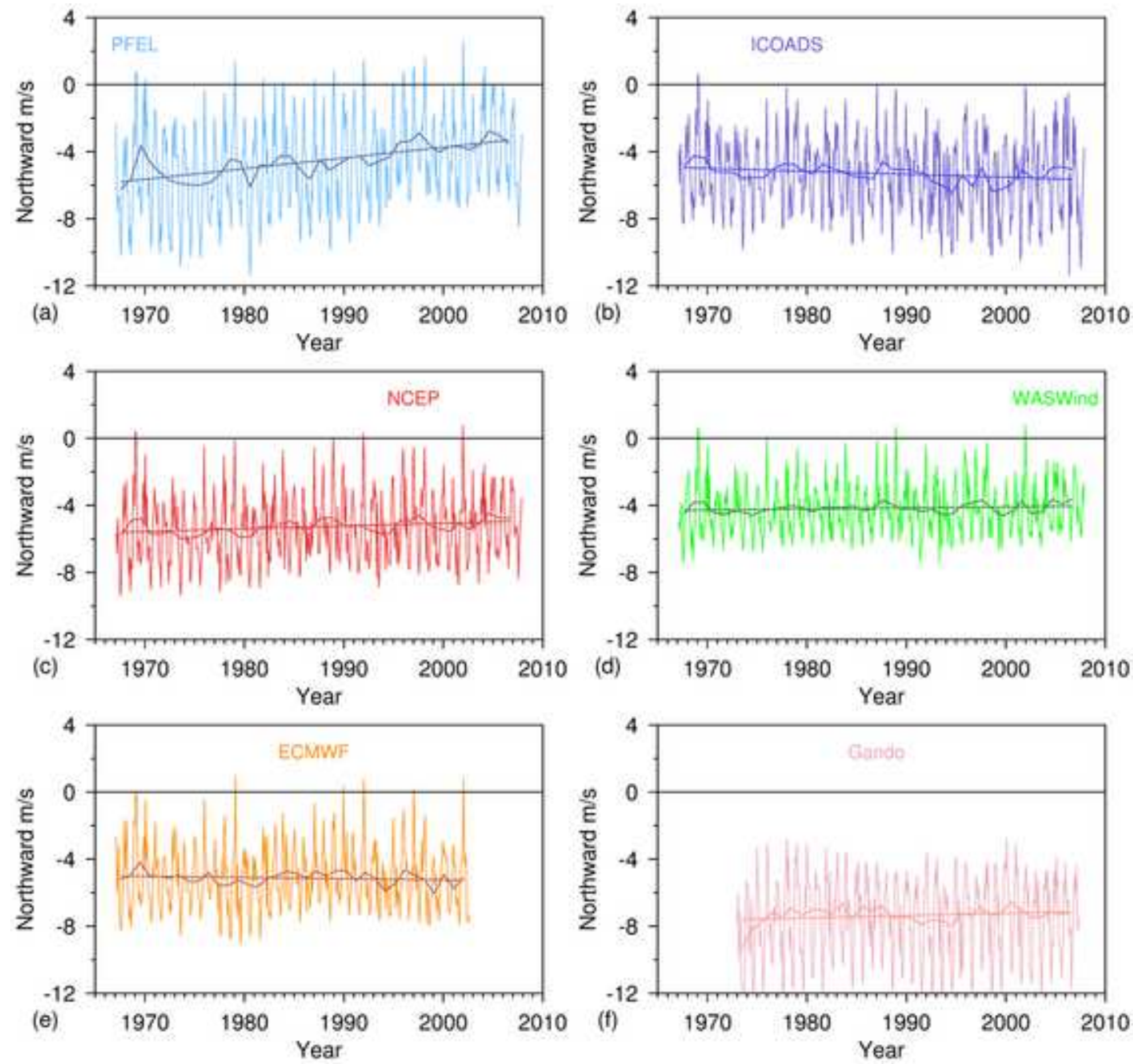

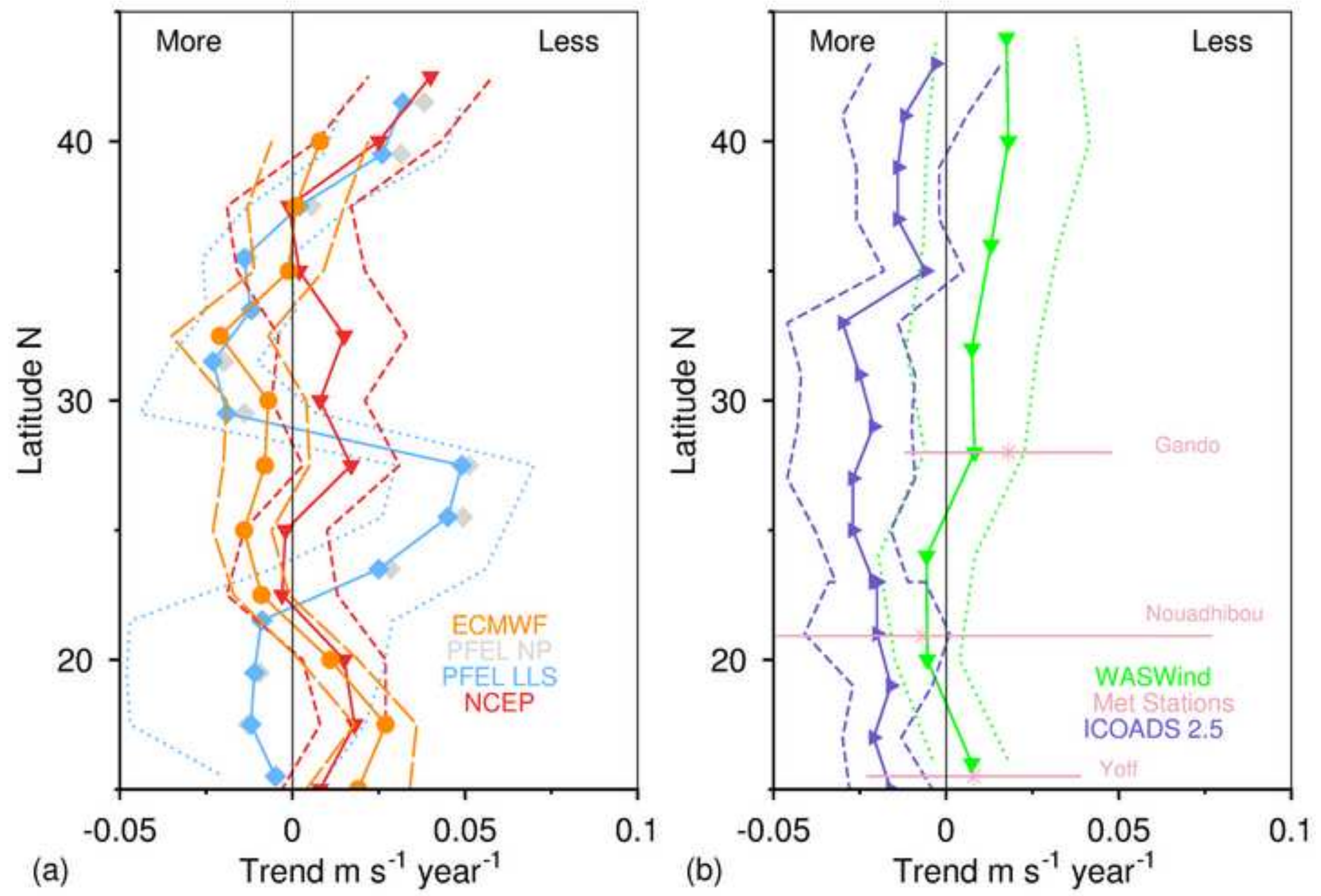


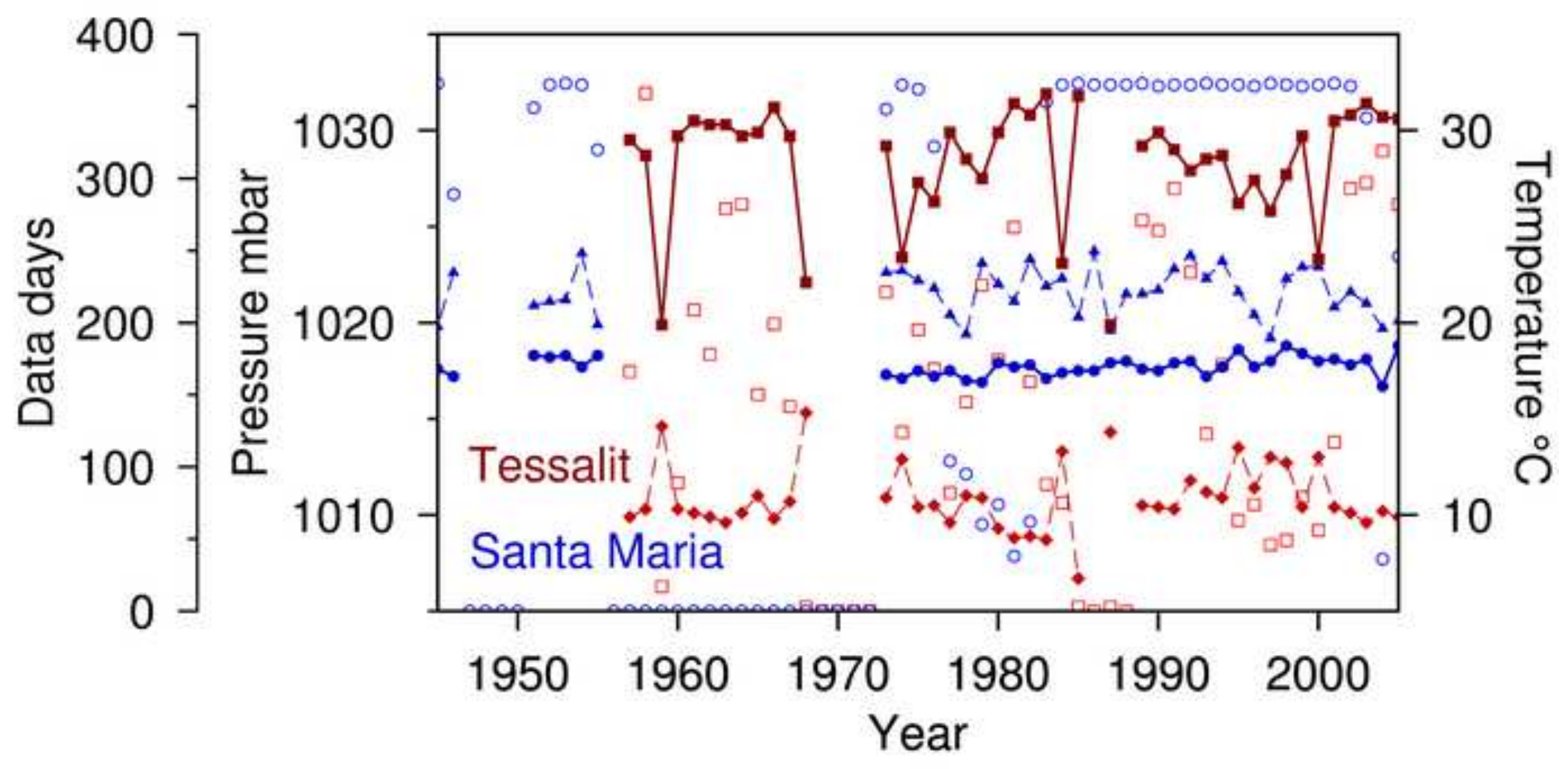



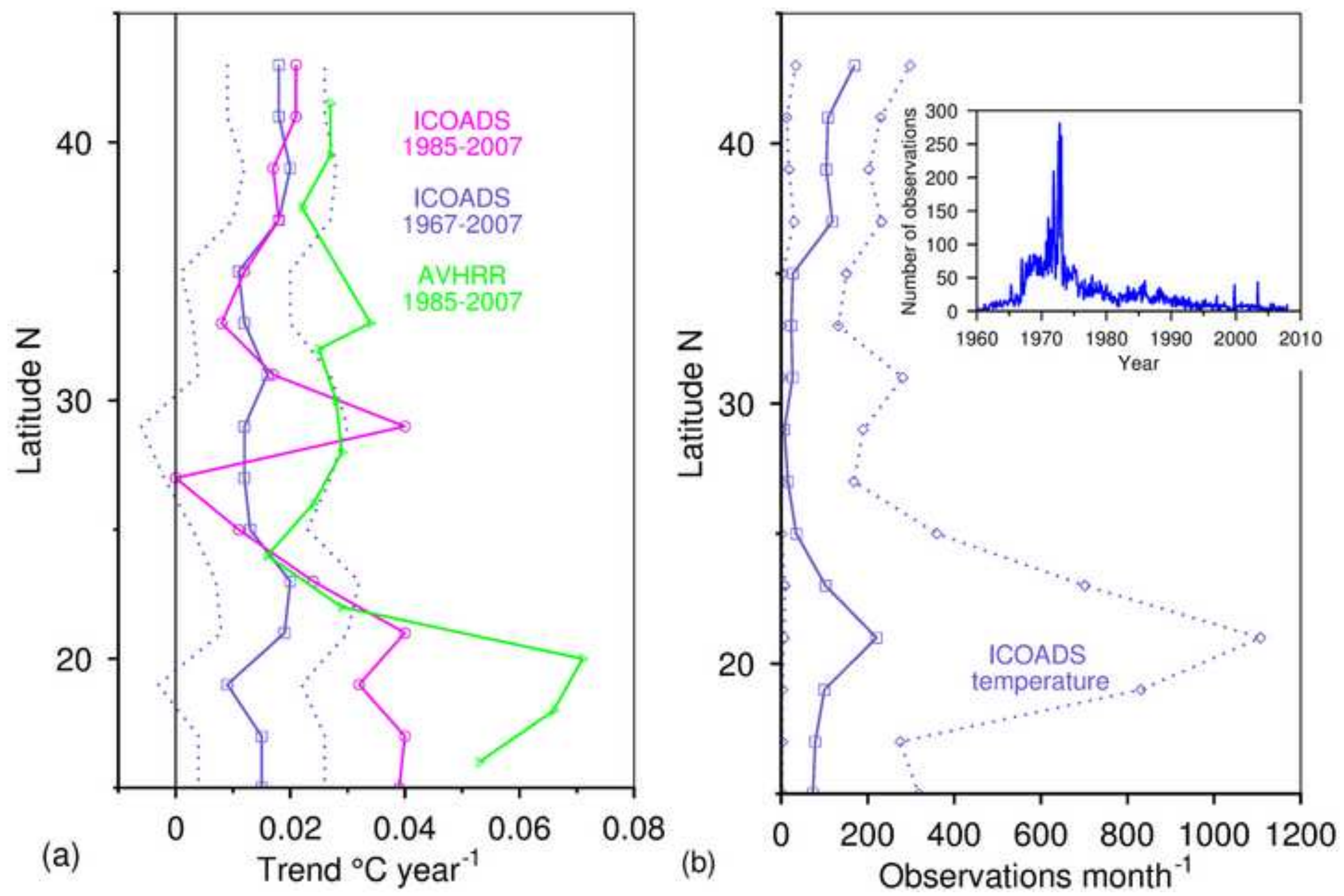


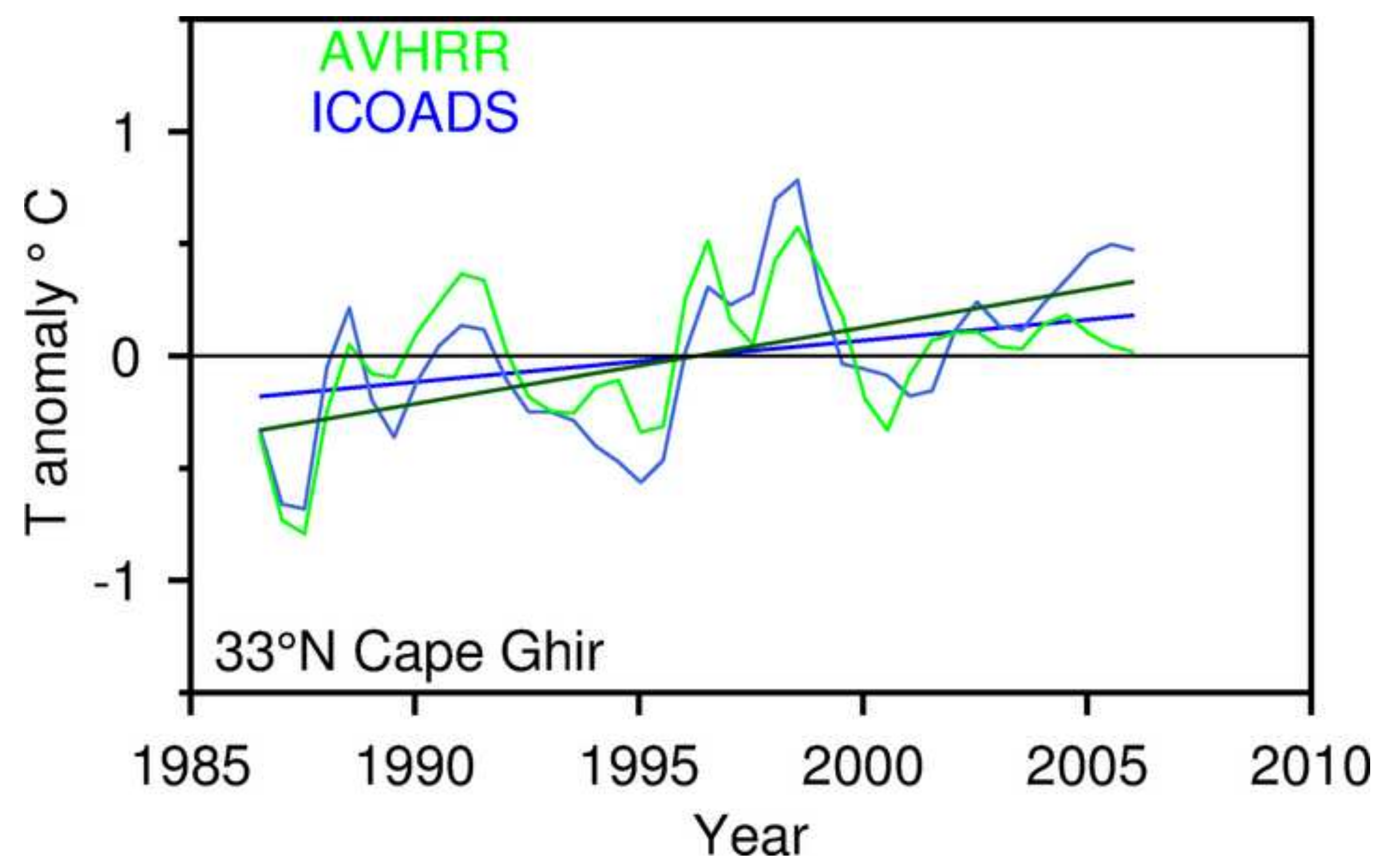


Figure

Click here to download high resolution image
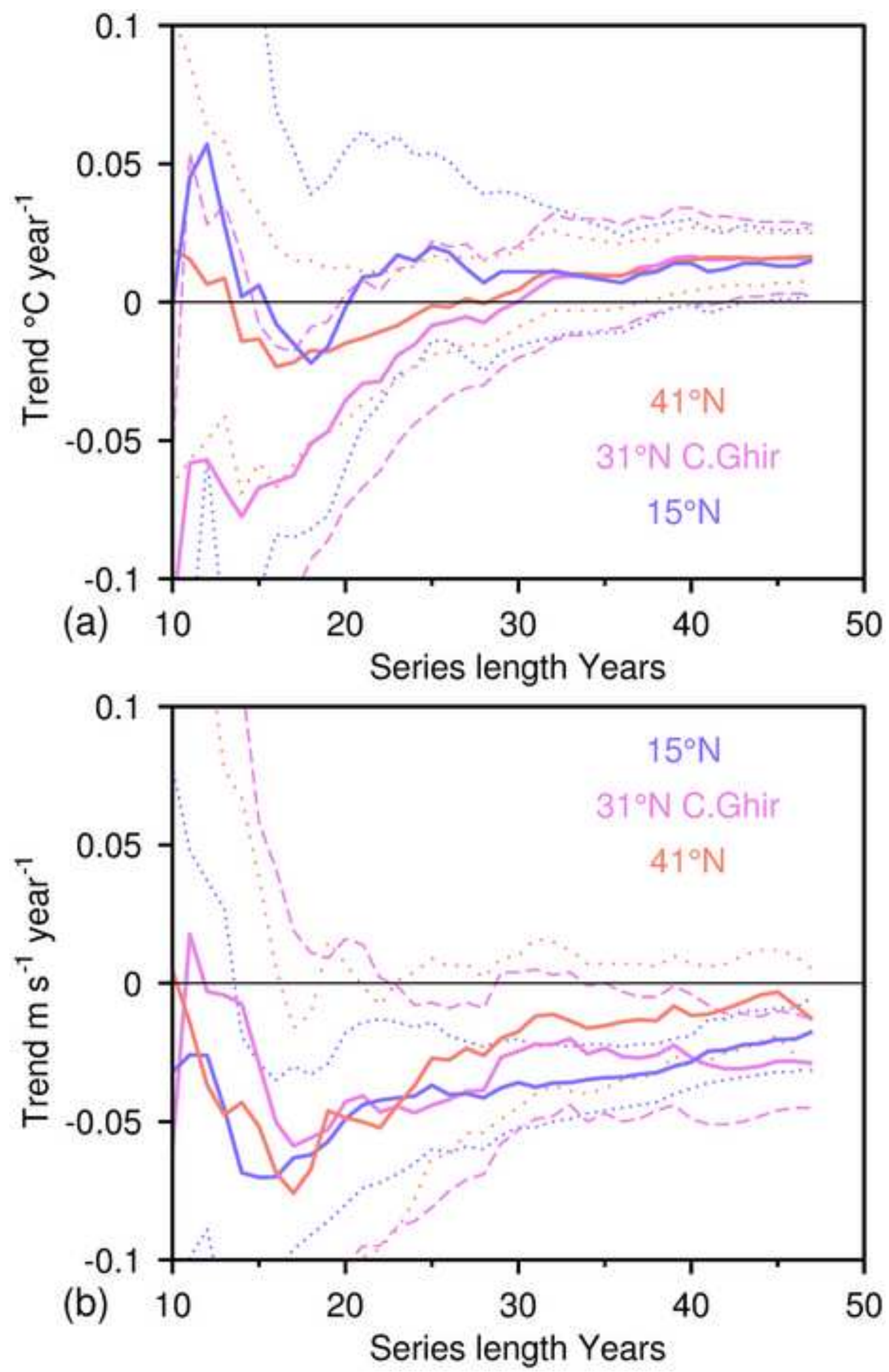


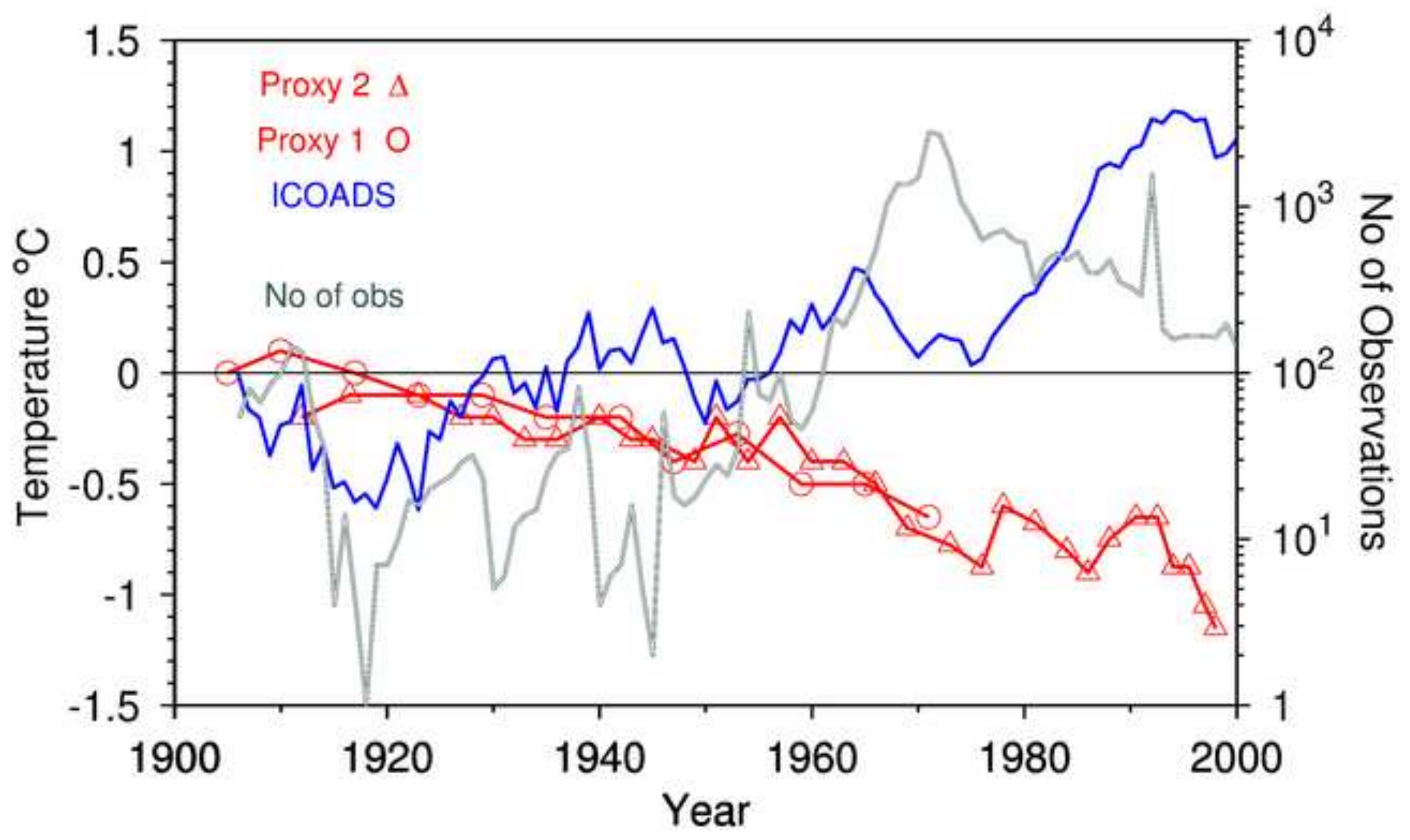




\section{Figure}

Click here to download high resolution image
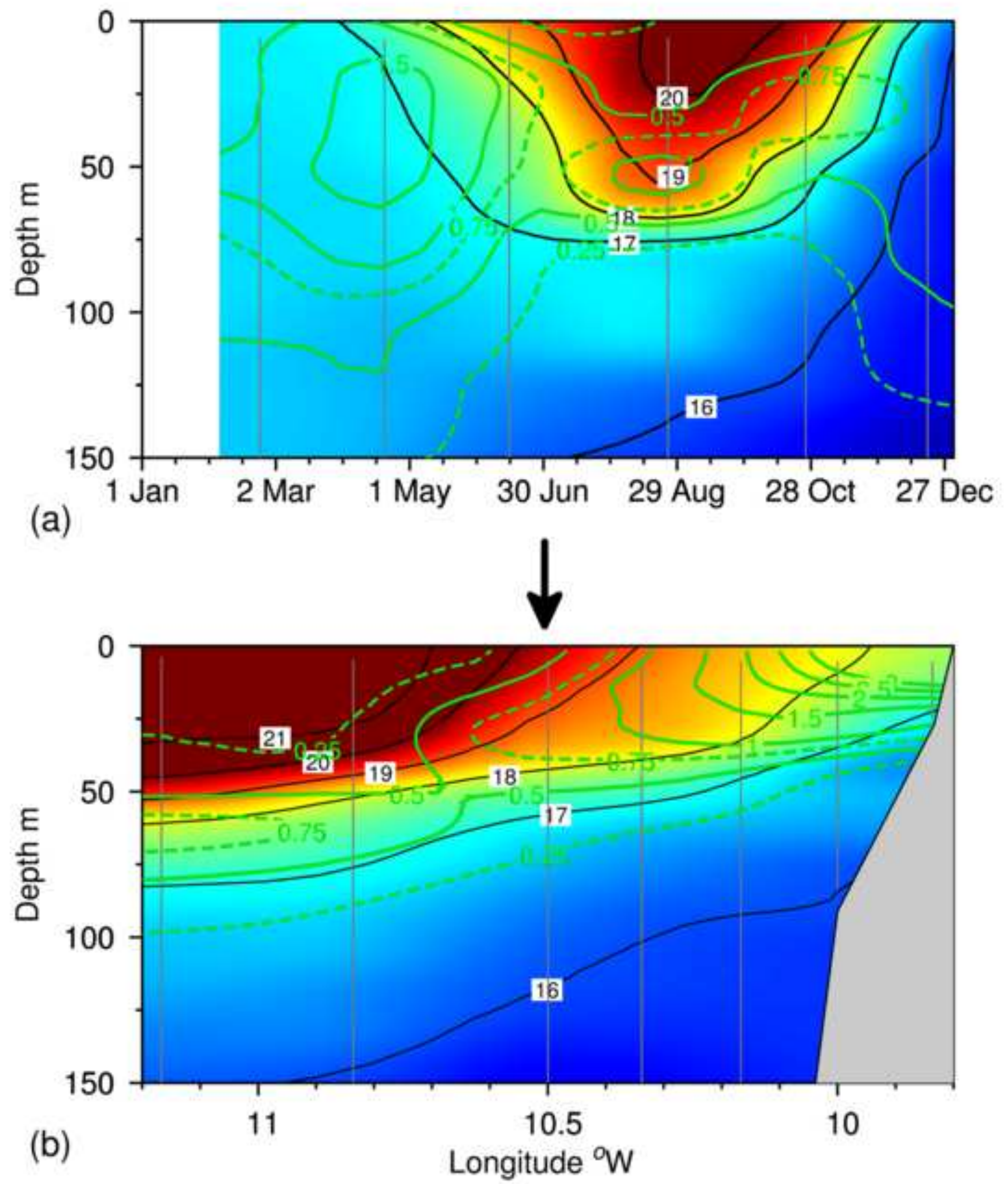